\title{
Iranian Enamels (Minakary) History
}

\section{Sajedeh Norouzi*}

Faculty of Philosophy and Social Sciences, University Federal of Rio de Janeiro, Brazil

\begin{abstract}
This article is about the Iranian enamels history with scrutiny the history of metal in Iran. It was checked in two parts: before Islam and after Islam in Iran. The Iranian enamels history was checked before Islam in Medes, Achaemenid and Sasanid ages, and after Islam in Seljuq, Safavid, Qajar ages.
\end{abstract}

Keywords: Minakary; Metal; Copper; History

\section{Introduction}

For a detailed review of the history of minakary art in Iran we need to examine the history of metal detection be mankind. Where was discovered metal? And how could artists soft to this hard objects and work on it.The oldest works of art that human has created been discovered in a fertile region of the middle east that from the north, Mediterranean shore and Anatolian mountains and from the south, Tigris and Euphrates. In this fertile region been discovered the humans work in during the copper and bronze. The first signs of the use pure copper for making equipment and industrial tools that is formed by cold wickets. Has been discovered in Anatolian in the presence of the rich copper mines. There is dispute among archaeologist about the exact time of discovery of copper. Some archaeologists believe that copper is discovered of the first time in Egypt because there are a lot of copper mines in Egypt and discovered many works of ancient time in Egypt and some archaeologists believe that copper is not the first metal that humans discovered and the gold was the first metal that the humans discovered because the shiny gold particles was fascination to humans. For this theory they have not been found any things of Neolithic time. That prove discovered gold before copper and because there are a lot of copper mines in the nature and also the copper has ability to hearing wickets in the ambient temperature so we can say humans found the copper for making tools and materials needed. Nobody knows when built the first copper object by cold wickets in the world. The humans before to know metal and took it in him hands understanding soil and they understood that they can use it for make their accessories needed after over the years with increase human's knowledge about the nature and after many tests and many errors they could create art pottery because they knew that they can cook mud for making a durable object (the second half the fifth millennium BC). The initial furnaces for pottery firing caused that humans to again experience for making suitable furnaces for ceramics now they could melt metals in pottery containers and make their necessary tools. The first metal that humans could melt was copper. In ancient times they were used casting method for production of copper. They were beginning to melt copper and then poured it on the sand flat and after freezing made it into the desired shape by cold wickets with the advancement of knowledge and enhance the humans experience briquettes changed respectively of sand to rock and to pottery. Archaeologist evidence confirms that Iran's north and center were the first and the oldest of metalworking industry center. Iran has a lot of mineral resources. Iran has many natural resources in Alborz mountains, edge of the desert in Anarak near to Kerman, jiroft and Ahar. According to the excavation carried out in the first civilizations (India, Babylon, Oxus, Iran and Egypt) Iran was the first civilization in the world that was able to discover the metalworking industry and expanded it in the world. The objects found of the first civilization shows that has begun metalworking industry in Babylon, Oxus, India and Egypt are of the second half of the forth millennium BC. Researchers have discovered tow objects in Silk hill near to Kashan that their life estimated between four thousand to four thousand five hundred years $\mathrm{BC}$ that objects have known as the oldest objects that discovered in Iran. The copper objects discovered in Eblis hill near to Lalaeh Zar river in a hundered kilometers southwest of Kerman that their life estimated about four thousand eighty - three years BC [1]. For scrutiny about the metalworking art in Iran we should study it in two parts: pre-Islamic period and the next period of Islam. In pre-Islamic period we research in Medians, Achaemenian and Sassanid period and in the next period of Islam we research in Seljuks, Safavian, Qajar and contemporary period.

\section{Per-Islamic Period}

In ancient Persia have ruled five dynasties that include:
1. Medes 708 to $550 \mathrm{BC}$
2. Achaemenian 550 to $330 \mathrm{BC}$
3. Seleucids 330 to $250 \mathrm{BC}$
4. Parthian $250 \mathrm{BC}$ to $226 \mathrm{AD}$
5. Sassanid 226 to $651 \mathrm{AD}$.

We want discuss about metalworking art in Iran so we must study the dynasties in which the metalworking art by artists has changed and we can get a favorable result.

\section{The metal art in Medes age}

Around eight hundred years $\mathrm{BC}$ emerged a new government in Iranian plateau especially in west mountainous region of Iran. This new government founded a unity government in Iranian plateau by using cultural ties and ethnic commonalities in areas under their rules. This new government was Medes. When they settled in western regions of Iran took effect from there architecture especially of Elamite and community centers and they could have made a big change in their

*Corresponding author: Sajedeh Norouzi, Faculty of Philosophy and Social Sciences, University Federal of Rio de Janeiro, Brazil, Tel: + 5521 3938-9600; E-mail: Sajinorouzi@gmail.com

Received September 14, 2017; Accepted September 18, 2017; Published September 22, 2017

Citation: Norouzi S (2017) Iranian Enamels (Minakary) History. Arts Social Sci J 8 : 299. doi: $10.4172 / 2151-6200.1000299$

Copyright: (๑) 2017 Norouzi S. This is an open-access article distributed under the terms of the Creative Commons Attribution License, which permits unrestricted use, distribution, and reproduction in any medium, provided the original author and source are credited. 
architecture. According to the objects been discovered in the Ziviyeh area (regional in Kurdistan) and according to pottery discovered it seems that Medes took effect from other ethnic groups in the Iranian plateau and Scythians (they were relatives of Iranian descent that lived in eastern part of the Caspian Sea and Turkmenistan and later, they stayed in Sistan and Zagros). This effect was in shapes and animal them that we can see it more completely in the Achaemenid art. One of the most prominent Medes art was metalworking art. Ziviyeh was the most important areas in this age for metalworking art that it was beginning of the Medes and Achaemenid metal working art. Medes were interested in animal motifs like lion's head, antelope sleeping with long spiral horns, bull that it's with combining artistic heritage design of indigenous people. We can see connection between the Medes metalworking art and indigenous people of Lorestan in bronze figurine of antelope that has been discovered in Hamadan. In Medes time expanded Iranian metalworking art in Salimey (Figures 1 and 2) [2].

\section{The metal art in Achaemenid area}

The Achaemenid was dynasty that ruled after Median in Iran. This dynasty was founded by the great Cyrus and that time Iran was the biggest rule in the world. According to Bistoun(in Kermanshah), Naghsh-e-Rostam(Fars), Parseh(Fars) inscriptions, Achaemenid ruled on Median, Elamite, Part, Babylonia, Assyria, Lydia(Armenia

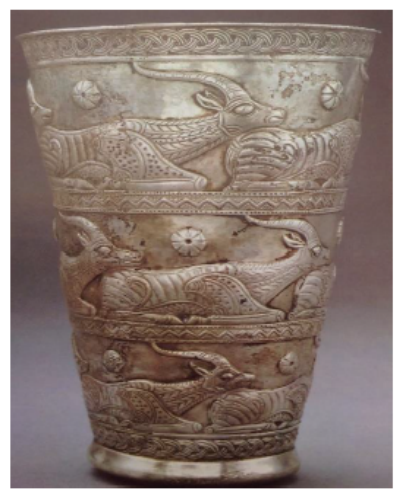

Figure 1: The silver cup discovered in Marlik hill that kept in Minneapolis museum it's from the Medes age.

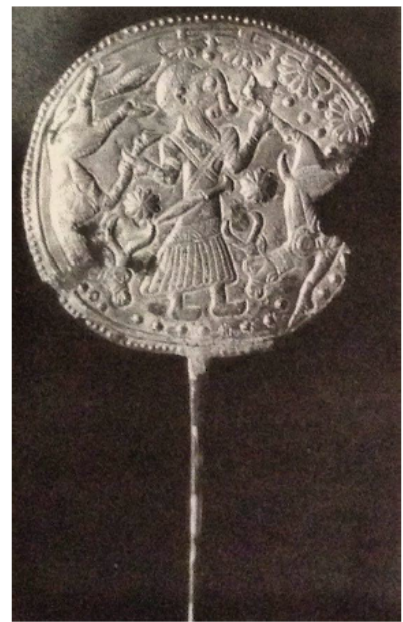

Figure 2: The bronze pins discovered in Lorestan that kept in Reza Abaasi museum it's from medes age. and Turkey), Phoenicia(Syria and Lebanon), Egypt, Ethiopia, Libya, Armenia, Greek islands in the Black sea, Balkh, Kabul, India, Scythian, Kharazm and Saudi. The metal working art was one of the main arts Achaemenid that we can examine it in terms of industrial, artistic and management. The Achaemenid metal working art is divided into two subdivisions: Mintage and Royal metal art. The Achamenid metal art it's formed of relying on their former craftsman experience. When the copper mine was discovered in the fifth millennium years BC it was used for wickets on raw metal and in third millennium years $B C$ been used of molten copper to be molded to build metal tools and containers. Iranian could expand their commercial relations because they had many copper mines so the relations would be changed the Iranian metal art [3]. In terms of art the Achaemenid arts was influenced Median art and artists like the Median age were interested to animal. Plant and human motifs. The animal motifs were of Median age and in the Achaemenid was be more beautiful and more perfect that was included of head or full body lion, winged lion, bull, winged bull, ram and antelope. The plant motifs were included of lilies, lotus flower bud, palmer flower, rosette flower and human motifs was included of the king head or him body or a soldier in the Persian dress. The interesting thing is we can see minakary on the some of metal discovered of Achaemenid age such as gold bracelet with lion figure that kept in Victoria Albert museum in London and Achaemenid necklace that kept in Miho museum in Japan and Achaemenid bronze bowl that kept in Los Angeles museum. According to documents obtained we can know it the minakary was beginning in Achaemenid age. The Achaemenid metal art is influenced of the past age art and has influenced on the after its ages art (Figures 3-6) [4].

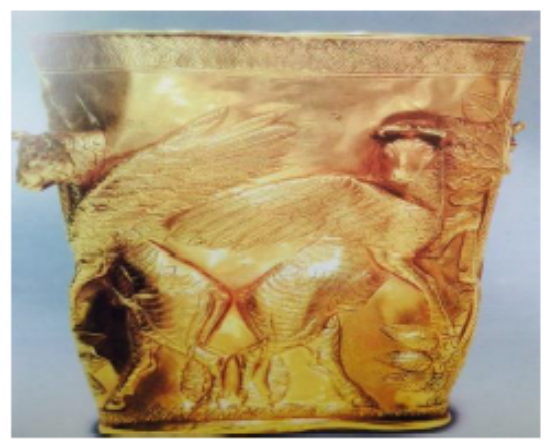

Figure 3: The gold cup discovered in Marlik hill.

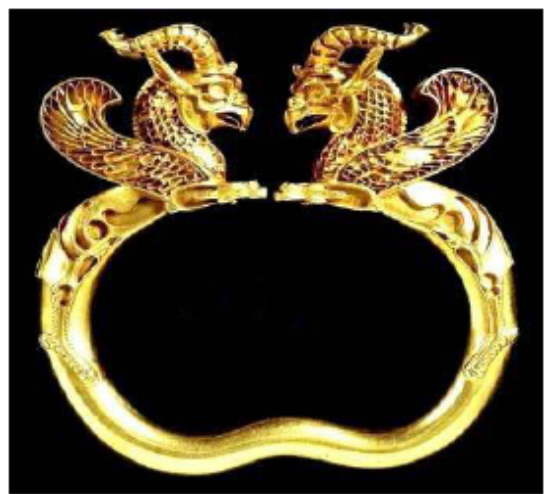

Figure 4: The Achaemenid gold bracelt that kept in Victoria Albert museum in London. 


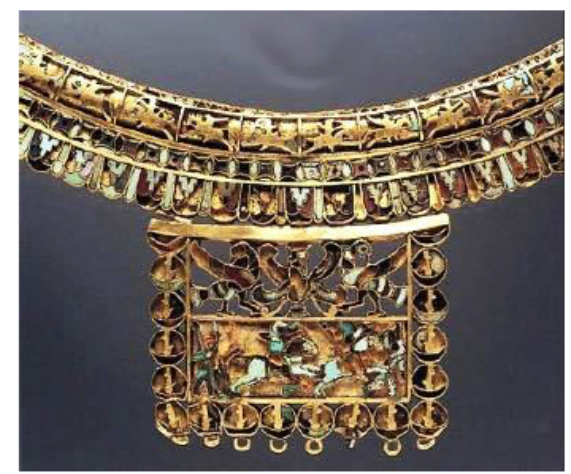

Figure 5: The Achaemenid necklace that kept in Miho museum in Japan.

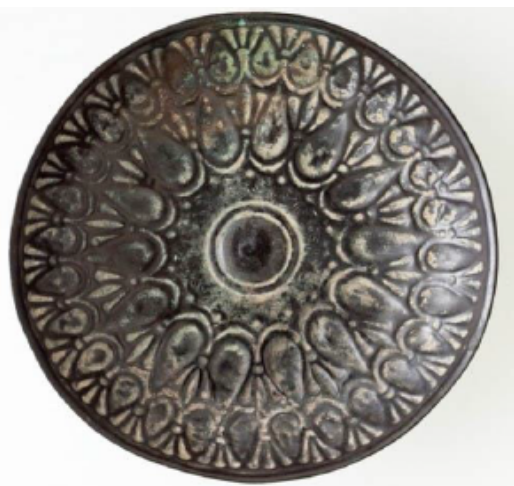

Figure 6: The Achaemenid bronze bowl that kept in Los Angeles museum.

\section{The metal art in Sassanid age}

Many art history researchers believe that flourished metal art in Sassanid time. The Silver was of metals that used it too much. The metal art in this time was one of the most prolific manufacturing industry that it was made in two ways: casting method with lost wax style and could wickets by using convex from for made metal objects. One of the oldest way for made objects with silver in Sassanid time was "double shell method". Never found any Sassanid silver that isn't made without two sheets of metal that one of them been used for the covered another template [5]. Roman Girshman confirms in his book "Sassanid and Parthian arts" the Sassanid silverware are ceremonial and their main motifs are image of Sassanid king. Of him opinion the Sassanid objects are exhibitive like their lithography because their made in royal workshop so they are indicative glorious king. The motifs drawn on the royal metal art the king always is with a crown even in unofficial events like hunting scene and private scene [6]. Ehsan Yarshater splits the Sassanid designed to four groups in his book "Iranian history of Seleucid until the collapse of the Sassanid" that include: silver plates, bottles with the women motifs, small bowl with design of king routine and events, and containers with animal and plant motifs with various decorative motifs [7]. These motifs are imitated with changes in the next period of Islam. It seems the Sassanid artists made the examples for all social classes and people made the containers of bronze, copper, iron and even their made on the glasses and tile by imitating of the original was worked on the gold and silver [7]. We can see a Sassanid plate with minakary in Metropolitan museum in New York that design on its Sassanid empire ram hunting. So we can see that minakary continued in Sassanid time but we can't see any progress in it. It was just a mina's first step that was started of Achaemenid time (Figure 7).

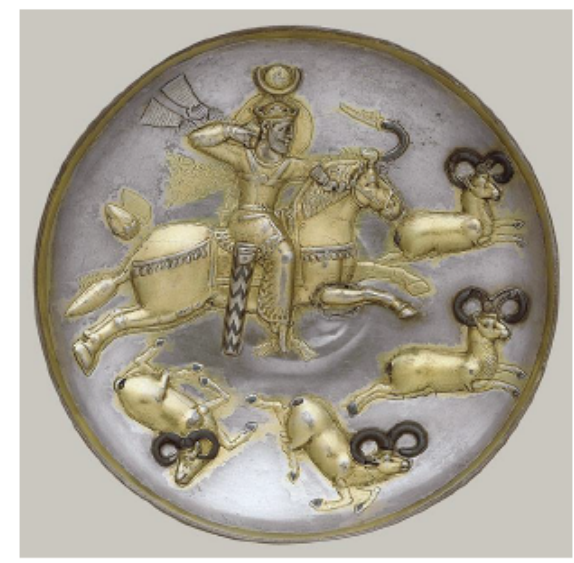

Figure 7: The Sassanid plate that kept in Metropolitan museum.

\section{Next Period of Islam}

After that Islam come to Iran impressed Iranian art and crafts and changed all art forms. In Islamic period in Iran the art industries come out of the royal court and it placed in service to religious purposes and the industrial art objects have been made that they be consistent with the spirituality of Islam. The metal art changed a lot of with what it was in the past. We can check these movements in the new containers and tools, invent new forms and unprecedented, change and development metals used, working techniques and using the new element of Arabic script as a metal decorated.

Dynasty that ruled in Iran after Islam are:

1. Taherian 826 to $881 \mathrm{AD}$

2. Saffarids 886 to $903 \mathrm{AD}$

3. Samanian 819 to $999 \mathrm{AD}$

5. Buwayhid 945 to $1055 \mathrm{AD}$

6. Ghaznavian 977 to $1186 \mathrm{AD}$

7. Seljuq 1038 to $1194 \mathrm{AD}$

8. Kharazamshahian 1077 to $1231 \mathrm{AD}$

9. Mongols $1228 \mathrm{AD}$

10. Ilkhans 1256 to $1336 \mathrm{AD}$

11. Timurid 1370 to $1506 \mathrm{AD}$

12. Safavid 1501 to $1732 \mathrm{AD}$

13. Afsharian $1734 \mathrm{AD}$

14. Zand 1750 to $1796 \mathrm{AD}$

15. Qajar 1779 to $1924 \mathrm{AD}$

16. Pahlavi 1924 to $1979 \mathrm{AD}$

17. Islamic Republic of Iran 1979 to today AD.

We want check three Iranian dynasties: Seljuqs, Safavids and Qajar because in these dynasties we can see that has improved Iranian metal art.

\section{The metal art in Seljuq age}

The Seljuq was originally the Turkman desert tribes round from 
Kyrgyzstan in central Asia that founded their reign in early in the fifth century AH with capture a large part of Transoxiana. The Seljuq dynasty founded by Tughril in the year 447 AH Helen Brand [8]. Seljuq after get into power and expand their empire of central Asia to Egypt it was cased that create a kind of scientific and artistic renaissance in the Islamic world especially in Iran. The cultural space was cased the kings and the rich people to backup artists. This extensive support in most cases followed the political goals but it was cased that create a new particular style in arts that later the researchers of Islamic art called the Seljuq style. In all the Seljuq arts and crafts can't be found any element or resource out of Iranian art and culture impact. While they were Turk but it's difficult to find any Turkish elements in Iranian art. This point shows Iranian artists dominate the visual arts [9]. In this age the metal art and production of metal artifacts gain highest quality and in this context Khorasan had great progress in metal art in that time. Perhaps this was due to the Khorasan have been privileged because it was a largest center procurement and production of bronze containers in Samanian age and decorated them to Sassanid way by Mohammad. Hassan [10]. The Seljuq age was the golden age branches of knowledge, crafts advances and the spread of Islamic art especially for metal art. Whereas the Iranian Islamic metal art was the continuation of Sassanid art but with the difference that in Islamic period had been banned using of precious metals like gold and silver and Iranian artists built metal objects of bronze, iron and brass. Changes in materials and religious attitudes was cased development this industry especially in Iran eastern states. In this age metal art achieved to a special development so that this technique remains stable always in a high level of build quality and it accomplish unique artistic purpose. This purpose was achieved by a large number of metal containers especially those that were produced in Khorasan. Many of these works had date and signature of artists, industrialists and designers [11]. In the Seljuq age artists used of metals such as gold, silver, iron, copper, lead and tin that used in the other post-Islamic periods. In this age the artists used a lot of brass that comes from combination of copper and zinc because it was the color of gold so it was a good alternative to gold. In the Islamic period in Iran hasn't been used of iron more just used for made instruments of war, lock and key and window frame [12]. The Seljuq metalworkers made of gold and silver container and objects just for rulers but is left of this objects lot. the only remains of them is a set of silver that are with various forms that they kept in Arab museum in Cairo. The most prominent effect of metal in Seljuq age and all Islamic period is a silver dish that famous by Alb Arsalan, this dish is thin and shallow and have Kufic inscriptions. Hassan Kashani made that in $495 \mathrm{AH}$ from queen to king [13]. In this age the method of making metal objects it's like the past periods and we can divide it in 3 parts: 1 . wickets methods with objects made of copper, iron, brass sheets and rarely of gold and silver. 2. casting method with objects made of brass and bronze, and rarely of copper [14]. The objects that made from a combination two past techniques. In Seljuq age decorated metal objects done with two ways: casting method and etching method that etching method divided to six ways: 1 . Fretwork, 2. Engraving, 3. Lattice work, 4. Tarsi, 5. Niello, 6. Minakary. In some reference kike industries on Iran after Islam written by Zaki Mohammad Hassan is mentioned to making mina and them quality in Seljuq age but the writer has refused of explanation about them because there isn't objects for them validity. Arthur Pope in him book (Iranian art masterpieces) is writing about construction designs on containers: in Iran has spread two opposite way or complement each other, one of them is completely cover the metal surface with multiple designs and this means were beautiful the containers and another way was that leave background be simple for show featured designs. They did Some of this backgrounds polished and glossy like the renaissance bronze work
[14]. On Seljuq objects and containers were enforced types of designs with different techniques as follows: using compact designs, eslimi and decorative ivy in the background with frequent vagireh. Using a lot of scrolls, using of human face sun with constellations, using of winged animal motifs, sphinx, using of human motifs in various scene, using of animal motifs in different modes symmetrically on the hunting scene, using of plant designs like wheat, using of seven full flower design that it was for Khorasan metalworking and using of encapsulated designs in geometric works knowns as designs armband (Figure 8).

\section{The metal art in Safavid age}

Safavid age is a best age in the Iranian history and we can know it the beginning of a new level in Iranian Islamic period history. After the Iranian Safavid family came to power, founded Shia religion as Iran's official religion. Always had been discussed about the Safavid family between scientists and historians for example Walter Hytnes believes that king Firouz ancestor of the Safavid was moved of Yemen to Azerbaijan for this reason he knows them Arabs. As well as Ayalon claimed that Safavid were Turkish. But Kasrawi after scrutiny evidence concludes that Safavid were indigenous Iran and they were originally Iranian but they spoke in Azeri that is native in Azerbaijan. The only confusion for Kasrawi was: were the Safavid for a long time in Azerbaijan or they emigrated of Kurdistan?. The Safavid dynasty is very important and in terms of historical and art. There are some reasons in this context that include the Safavid were originally Iranian and they were the first independent government in Iran after Sassanid empire and they restored Iranian traditional boundaries and some elements and ancient values again. Another Safavid characteristic is, Safavid art during; that time was properly the golden age of Iranian art. In Safavid age formed types of Iranian art like metal art, miniature and specially carpet weaving. Iranian metal art was reflection of the society that created it. Lifestyle, intellectual pursuits, ideals and wishes rulers were expressed through value and operation. In the thing that they used metal art as an art-industry was very important between another artindustries. In this age new attitude caused that arise significant changes in construction, form and practicalities metals effect. So that engravers and tarsiekaran traditional skills appears again and rugged power gives its place to suitability and charm. Persian language and script take the Arabic script place; the artists could paint human, animal, flower and trees. In Safavid age the metal art found dimensions range and flourished a lot make and etching artifacts gold, silver, copper. Brass. The tarsiekary art on the brass that was destroyed in Mongols and

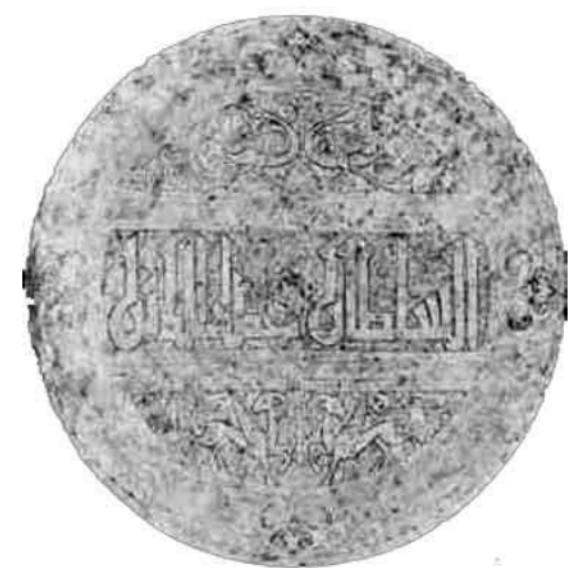

Figure 8: Silver trays, with Alb Arsalan inscription that kept in Boston museum. 
Timurid flourished again in this age and they did white the copper utensils because they wanted be such as silver. They used of iron and steel for made objects. Decorating in this age was indicative changes in the verve and time style. In this age we can see artist skill and genius in metal art that was based on old traditions and artist skill. In this time beauty and elegance were replaced the past intensity and violence for example the Seljuq large and voluminous geranium that were on the body of the drum-like took its place to the beautiful geranium. In this age other arts like calligraphy added to metal art that caused enhance the beauty in the decorative work. Etching art on metal and calligraphy mixed with metal art and it created in this time immortal works in metal art. Delicately and use of calligraphy as a decorate are the details of Safavid metal art and is seen in most of the metal Persian poetry and holy names. The metal art artists in Safavid age brought metal art to the utmost perfection. Brass candlesticks that decorated the leading figure or are engraved were of the most important works in this period. One of them kept in Metropolitan museum in America and its production date arrive to $986 \mathrm{AH}$. They have decorated with scrolls and Persian poetry and plant designs that were enforced on all surfaces. Zaki Mohammad Hasan according to debris of metal art in Safavid age says: in the Safavid metal art been used of yellow copper that was very shiny and was like gold but they did white the combination of red copper and tin like silver. On the Safavid containers it can be seen more flowers motifs, bush and eslimi design and sometimes it can be seen human painting and calligraphy on the containers. It can be said that in this age more decorative motifs and tears in metal works are used as follows foliage plant and human and animal motifs that it reminds the carpet designs and manuscripts pictures. This happened clear for us an important point that is a close relationship between all the arts in this age for example we can be seen close relationship between miniature and metal art and also the artists in this age had freedom to picturing human, animals and plants motifs and in Safavid age has spread eslimi that Iranian were the real masters in it. In this age these motifs been used in carpet weaving, tiling, illumination and plasterwork and the Arab's designs like calligraphy, geometric shapes and judging Kofi have been gradually abolished. The best and most beautiful Safavid metal art is shown on the sixteen century miniatures. Only remains a small number of these objects that kept in Topkapi museum in Istanbul (Deimand: 2004, P 154-3). It was in this age that the metal art artists could combine the metal art with other arts like lattice work and they could bring it to the fullest. Ehsani believes that the Safavid artists could bring lattice work to the fullest in this age and they turned it to a global masterpiece; they were able to soft the hardened metal sheets in the artist hands like paper and pen in calligrapher and painter hands (Figure 9).

\section{The metal art in Qajar}

After the death of Karim Khan Zand, Agha Mohammad Khan Qajar fled from Shiraz that was the capital city in Zand age and after

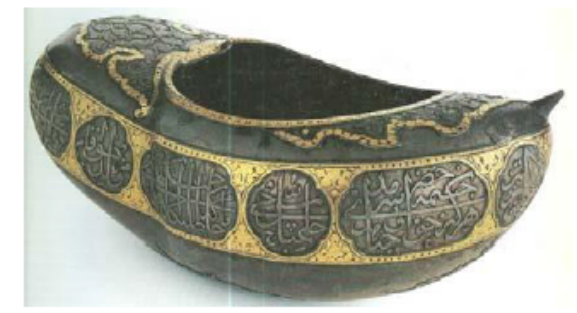

Figure 9: Gilded Kashkool, eleventh century, princes Sadr Alddin Agha Khan collection. the many battles he could destroy the Zand dynasty and he been the king of Persia. Agha Mohammad Khan could unite the Qajar Turkic tribes together and he consolidated him military force. The Qajar dynasty began with Agha Mohammad Kahn Qajar and ended with Ahmad Shah Qajar. This reign ruled on Iran about one hundred and thirty years. As mentioned after the coming of Islam to Iran and prohibition using of gold and silver the artists started to use other metal like iron, copper and bronze and they made beautiful containers that was indicative them skills and style. The metal objects of in this age that there are examples like tray, flower pot, box, water tight and ... kept in private museum and state museum have the beautiful decorative. The artists to decorate these objects used of different calligraphy, geometric patterns, high relief and eslimi designs. When the Safavid ruled in Iran the artists could use of gold and silver and they made the beautiful objects of gold and silver. In Qajar time the artists made the containers that had industrial aspects and they painted on them with Mina. In the Qajar age the artists made of gold and silver hookah and they have created high relief on them and they decorated them with mina and precious stones. In Isfahan the artists made bronze containers like large and small tray, cresset, bowl, plate, candlestick and silver containers and they decorated on them with planet design and other designs. The most important relic of in this time is peacock thorn or sun thorn that made in $1215 \mathrm{SH}$ by goldsmiths, stone cutters, minakaran and Isfahanian designers. This thorn kept in Tehran jewels museum. Method of decoration metal objects in Qajar time had little difference with before its age and this method as follows:

1. Casting: this method was of ancient time that used for decorated metals. In Qajar time in addition to traditional methods entered new way of casting to this industry from England and Russia. Casting is the method of making an art object by pouring metal splash into the casting mold. Etching and engraving: it's the method of dropping onto a hard surface by scraping with a sharp tool or creating troughs and ridges by special etching tools. Acid etching: it's method of dropping a metal by acid according to the metal corrosion ability by acid. At the first they executed their design on the metal and after that they covered the designs with a thin layer of lacquer and they put the metal into the acid. After that the metal corrosion full and creating troughs in the desired designs they removed the metal of acid and they clean up the lacquer by gasoline or oil.

2. Latticework: it's any decorative on the object that could broke to the other side of the object

Types of plant decorations, eslimi, khataei and twisted designs, decorating writing, scrolls and metal discs work with this technique.

3. Inlay: it's corrugated metal by gold and silver. it's famous to gilt work and zarkub. At the first the artists define the inlay place and after that by the inlay knife scratch the desired location like multiplied sign then they fill the inlay place by gold and silver wire and they smooth its surface with jade or agate. They by much banging make pure gold to the belt and then bring them to square and then they leave them lay among the papers of fibers berry, tragacanth or gut and they beat them with heavy hammers when to reach to thickness 0/000375 centimeters.

4. Monagharkary: this technique is like inlay technique but with this difference that in this technique the artists used of silver powder. They combine the silver powder with water and then by brush let it on the metal and when heat metal, silver fix on the metal.

5. Forging: it's wickets on the metal surface for achieve a threedimensional form or volume up to a two-dimensional surface that it used for making statues and hollow volumes. 
8. Tarsikary: it means the object that decorative with jewel. Artists used jewel on the enameled gold.

In Qajar time was decorated metal containers with animal, plant and human motifs, inscription and decorating writing. In Qajar metal art there was several methods for decorated metal objects that one of them was Safavid plant motifs, eslimi and khataei that was common in the Islamic age in Iran, painting flowers and birds, paisley motifs that was a pervasive element in the Qajar art. The sources of inspiration in Qajar age was Rococo plant motifs on the Europe metal objects in eighteenth century and combined it with flowers and bushes twisted engraved on Safavid metal objects. Painting flowers and birds as an independent and unique way in Qajar age defines new species of miniature flowers and plants. The plant motifs in the shadow of naturalism in this age has changed with the arrival of Farang flower or London flower and sometimes eslimi and khataei gave them place to easier plant designs and realistic like rose, clove, acacia and lily flowers. Paisley is a plant design that was very useful and effective in Qajar metal art. Paisley been used on the crown and on the fabrics that they used in Qajar time. That is indicative importance this design in Qajar time that is inspired of cypress tree that is symbol of stability, immortality and originality. In Qajar time we faced with a new phenomenon that they had new design in them body and new practical and also we faced with symbolic animal that they have religious use (statues of lions and symbolic birds like peacocks and pigeons). In a general classification we can divide the Qajar metal art with animal motifs in two categories: The objects with animal motifs and the objects with animal-shaped body. The Qajar miniature was under the influence European paintings and also vogue photography and painting from the photo caused be created a look naturalistic. In Qajar time the artists with inspired of the Qajar painting were carved on the metal religious events, the Qajar kings scenes of them feasting and hunting and copy of European works. Minakary is shown obvious in Qajar time that it was more of a monarchy art and it was used on the hookah with human designs (Figures 10 and 11).

\section{Conclusion}

About minakary in Iran and it dating back according to investigations and historical evidence we can say it started of Achaemenian age to today. Minakary is painting and decorated metals like gold, silver and copper by special glazed color that it fixed on

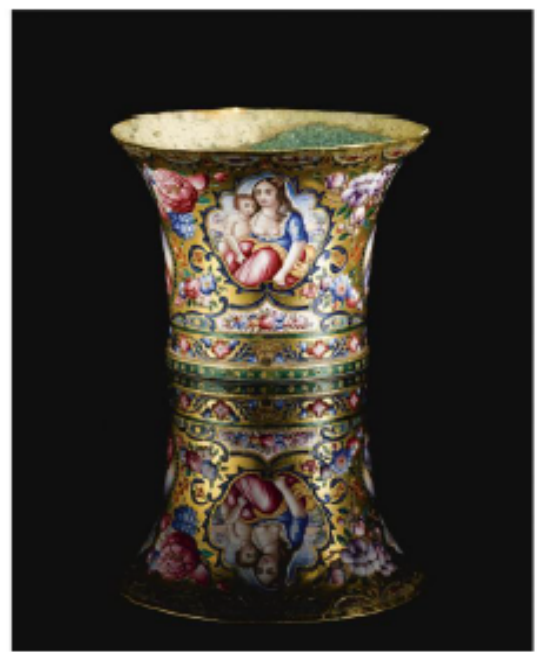

Figure 10: The Qajar minakary hookah that kept in Azerbaijan museum in Iran.

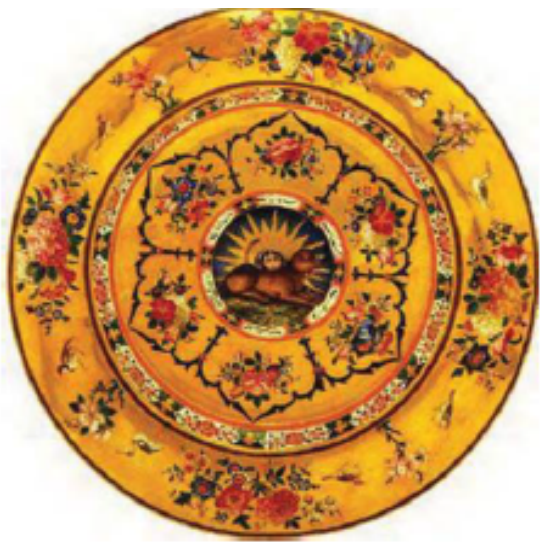

Figure 11: The Qajar minakary plate that kept in Azerbaijan museum in Iran.

highest temperature. Sometimes mina worked on the tile, ceramic and glass but mina's substance is metal and more copper. It's necessary to say the minakary sometimes work on the gold and silver. Now we should say it's can't be possible that would have existed colored glaze on ceramic and tile in a nation but they didn't use it on the metal. Any way ever been found any mina's objects that it be was in the same time with glazed pottery in Iran.

\section{References}

1. Tohidi N (1985) The evolution of iron and steel production in Iran. Tehran, p: 45

2. Salimy N (2006) History of Iranian art. Tehran, pp: 28-36.

3. Ehsany Md (2011) Seven Thousand years of Iranian art of metal working Tehran, pp: 31-74.

4. Calican W (2006) Archaeological and Art History in the Period of Materials and Persians. Tehran, pp: 123-124.

5. Yarshater E (1998) History of Iran from the Selukians to the collapse of the Sassanid government Cover, Vol-3, pp: 660-680.

6. Dimand SM, Ghirshman R (1933) Parthian and Sasanian art. Tehran, p: 204.

7. Bussagli M, Umberto S (1997) Parthian and Sasanian art. Tehran, p: 90.

8. Hillen Brand Robert (2006) Islamic Art and Architecture. Tehran, p: 85.

9. Batherhood (2001) Seljuqs Tehran, p: 160.

10. Mohammad Hasan Z (1987) History of Iranian Industries after Islam. Tehran, 15:16; 222.

11. Katli (1997) Seljuq and Khwarizmi art. Tehran, p: 37.

12. Pour L (1996) White face Tehran, Vol-12, p: 75.

13. Aurthor $P$ (2001) Masterpieces of Iranian art. Tehran, 85: 86; 2906.

14. Arthur $P$ (2008) Search in Iranian art. Tehran, p: 2906. 